\title{
The Constitutionality of Federal Removal Jurisdiction Over Separable Controversies Involving Citizens of the Same State
}

"The law relating to the rèmoval of causes from State to Federal Courts may be justly characterized as a snare and a delusion." I "That there is no other phase of American Jurisprudence with so many refinements and subtleties, as relate to removal proceedings, is known by all who have to deal with them." 2 These comments are particularly apt when applied to removals on the ground of separable controversies. The fog has been partially dispelled by exhaustive discussion of the characteristics of a separable controversy. ${ }^{3}$ On the other hand, only slight attention has been given to the constitutional theory underlying removals on this ground.4 This constitutional consideration is the subject of the present investigation.

Removal does not stem from the common law; ${ }^{5}$ it is a statutory creation. ${ }^{6}$ The separable controversy basis of removal was first introduced in 1866,7 at which time removal was limited to a defendant and to a

1. Lewis, Renoval of Causes (I923) 8.

2. Hagerla v. Mississippi River Power Co., 202 Fed. 771, 773 (S. D. Iowa 1912).

3. Dobie, Handbook of Federal Jurisdiction (I928) 369-381; Montgoniery, Mañual of Federal Jurisdiction and Procedure (3d ed. I927) \& 290; 3 Moore \& Friednan, Moore's Federal Practice (I938) § Ior.06; Simkins, Federai Practice (3d ed. I938) $\$ 98$, I021, I084, I09I; WIIliaArs, JuRIsDiction aNd Practrce OF FedERAL CourTs (IgI7) II3, I30, I35; Note. (I936) 36 CoL. L. REV. 794; Note (I928) 4I HaRv. L. Rev. 1048; (1934) Ig Iowa L. Rev. 482; (I932) 80 U. OF Pa. L. REv. 455.

4. See note 29 infra.

5. Chicago \& Northwestern R. R. v. Whitton's Administrator, 80 U. S. 270, 287 (I87I). Wenzler v. Robin Line S.S. Co., 277 Fed. 8I2, 8r9 (W. D. Wash. I92I): "The statute of removal of causes is no part of the common law. It cannot be said to be either a modification or extension of a common law right or remedy. It is merely the machinery for getting the case into the right court." DOBIE, HANDEOOK OF FEDERAL JURISDICTION (1928) 347: "Quite anomalous is this removal jurisdiction under which a defendant, sued in a court of competent jurisdiction, pro hac vice becomes dominus litis by electing a forum of his own choosing. His right of removal thus has not even a flavor of the common law; it is altogether statutory. Express warrant in a federal statute must be shown in each case for the removal; otherwise, the case must remain in the state court in which it is brought." LEWIS, REMOVAL OF CAUSES (I923) § I; Simmins, Federal Practice (3d ed. I938) \$\$ ior8, roig.

6. The basis for the statutes is: U. S. Const. Art. III, \$2: "The judicial Power shall extend to all Cases, in Law and Equity, arising under this Constitution, the Laws of the United States, and Treaties made, or which shall be made, under their Authority ;to all Cases affecting Ambassadors, other public Ministers and Consuls; - to all Cases of admiralty and maritime Jurisdiction;- to Controversies to which the United States shall be a Party;-to Controversies between two or more States;-between a State and Citizens of another State;- - between Citizens of different States,-between Citizens of the same State claiming Lands under Grants of different States, and between a State, or the Citizens thereof, and foreign States, Citizens or Subjects."

7. Act of July 27, I866, I4 STAT. 306 (I868), 28 U. S. C. A. \$7I (I927) : That if in any suit already commenced, ".. and if the suit so far relates to the alien defendant or to the defendant who is the citizen of a state other than that in which the suit is brought, is or has been instituted or prosecuted for the purpose of restraining or enjoining him, or if the suit is one in which there can be a final determination of the controversy, so far as it concerns him, without the presence of the other defendants as parties in the cause, then and in every such case the alien defendant, or the defendant who is a citizen of a state other than that in which the suit is brought, may at any time before the trial or final hearing of the cause, file a petition for the removal of the cause as against him into the next circuit court of the United States to be held in the district where the suit is pending. . . Note, p. 5 . 
separable controversy only. The Act of $\mathrm{I} 867$ extended the right of removal of a separable controversy to either a plaintiff or defendant. ${ }^{8}$ The Act of 1875 permitted removal of a suit by a plaintiff or defendant if within it there were a separable controversy wholly between citizens of different states. $^{9}$ The Act of $1887,{ }^{10}$ which was severely criticized for its lack of clarity, ${ }^{11}$ restricted the right of removal of a suit to one or more parties

8. Act of March 2, 1867, I4 StAT. 558 (1868), 28 U. S. C. A. \$7I (I927): This Act amended the Act of 1866 and stated: "That where a suit is now pending, or may hereafter be brought in any state court, in which there is a controversy between a citizen of the state in which the suit is brought, and a citizen of another state, such citizen of another state, . . . whether he be plaintiff or defendant, if he will make and file, in such state court, an affidavit stating that he has reason to and does believe that, from prejudice or local influence, he will not be able to obtain justice in such a state court, may, at any time before the final hearing or trial of the suit, file. . . for the removal of the suit into the next circuit court of the United States to be heid in the district where the suit is pending." Note, p. 6.

9. Act of March 3, 1875, r8 STAT. 470 (1875), 28 U. S. C. A. §7r (1927): "Sec. 2. That any suit of a civil nature, at law or in equity .. . arising under the Constitution or laws of the United States, or treaties made, or which shall be made, under their authority, or in which the United States shall be plaintiff or petitioner, or in which there shall be a controversy between citizens of different states, or a controversy between citizens of the same state claiming lands under grants of different states, or a controversy between citizens of a state and foreign states, citizens or subjects, either party may remove said suit into the circuit court of the United States for the proper district; and when in any suit mentioned in this section there shall be a controversy which is wholly between citizens of different states, and which can be fully determined as between them, then, either one or more of the plaintiffs or defendants actually interested in such controversy, may remove said suit to the circuit court of the United States for the proper district." Note, p. 7 .

Io. Act of March 3, I887, 24 STAT. 552 (I886); and the correction of that Act by the Act of August I3, I888, 25 STAT. 433, 434 (I889), 28 U. S. C. A. \$ 7 I (I927): "Sec. 2. And when in any suit mentioned in this section there shall be a controversy which is wholly between citizens of different states, and which can be fully determined as between them, then either one or more of the defendants actually interested in such controversy may remove said suit into the circuit court of the United States for the proper district. . . " Note, p. 8.

For more complete text see note 13 infra quoting the Act of IgIr, which was stated in terms almost identical to the Act of $1887-8$ except for the use of the words

Ix. Note the criticism of John F. Dillon, Circuit Judge of the Eighth Circuit, in Dilion;" ReMoval of CAUSES (5th ed. I889) \$35: "This statute [Act of I887] enacts the most radical and sweeping changes in the law upon this subject, and is evidently designed to remodel the whole system of the jurisdiction of the Circuit Courts. This being the case, it was very much to be desired that its language should be clear and precise and its provisions perspicuous and free from doubt. Unfortunately, the opposite is true. Parts of the act in question are obscure and very ambiguous; in several places its language is extremely confused; and both the meaning of the act itself and its intended effect on previous cognate statutes are open to serious question. Indeed, as the act was first officially promulgated, the profession was astonished to find that it so abounded in errors of grammar and orthography as to be, in places, absolutely unintelligible." Also that of Emory Speer, United States Judge for the Southern District of Georgia, in SPEER, REMoval OF CAUSES (I888) 9, Io: "The radical and comprehensive alterations in the jurisdiction of the Federal Courts effected by the Act of Congress of March 3,1887 , will render a brief treatise thereon of immediate usefulness. The subject is of great and urgent importance. The legislation conferring jurisdiction upon the National Courts, or limiting or withdrawing jurisdiction already conferred, should be as plain and as intelligible as the organic law itself. It is lamentably true, however, that it is obscure and ambiguous; that the unjustifiable practice of changing laws so momentous as these, in the turmoil, impatience, partisanship, and confusion incident to the closing hours of a Congressional term, is for every reason deplorable. It has produced much litigation under the Acts of March 2, I867, and March 3, I875, while the Act of March 3, I887, has left jurisdictional statutes, upon which the gravest consequences depend, in a state of apparent doubtfulness which will necessitate more time for comparison and study than is usually available to the counsellor or attorney, in full practice, or the nisi prius judge in term." 
defendant actually interested in a separable controversy. ${ }^{12}$ The current Act of I9II ${ }^{13}$ continues the lamentable ambiguity of its confusing ancestor, the Act of 1887 . In the first sentence of the present Act, providing for removal of federal question cases, the following terminology is used: "Any suit ... of which the district courts ... are given original jurisdiction. . . The second sentence in providing for removal of diversity cases refers to: "Any other suit . . . of which the district courts . . . are given jurisdiction. . . Next the sentence responsible for much of the confusion states: "And when in any suit mentioned in this section there shall be a controversy ... wholly between citizens of different states . . the defendants actually interested in such controversy may remove said suit. . . ." The following sentence referring to local influence and prejudice as a ground for removal uses the words "a suit." What, therefore, is "any suit mentioned in this section"? Does this mean only a suit of which the federal courts would have original jurisdiction? If not, is the assumption of jurisdiction constitutional?

Because the Acts of I866 and I867 allowed removal of only a separable controversy which involved citizens of different states, there was no need for a discussion of the constitutionality of the removal. After the passage of the Act of 1875 , however, there was some comment upon the legality of that Act and its effect on the scope of federal jurisdiction. ${ }^{14}$ That Act provided inter alia:

“. . . and when in any suit mentioned in this section there shall be a controversy which is wholly between citizens of different states, and which can be fully determined as between them, then, either one or more of the plaintiffs or defendants actually interested in such controversy, may remove said suit to the circuit court of the United States for the proper district."

In I876, Judge John F. Dillon discussed the Act and decided that under it the principles of the early decisions, stressing the requirement of

I2. Dillon, Removal of Causes (5th ed. I889) 42: "As we have already stated, the Act of 1887 is a reactionary measure."

I3. Act of Márch 3, I9II, 36 Stat. 1094 (I9II), 28 U. S. C. \$ 7I (I927): "Any suit of a civil nature, at law or in equity, arising under the Constitution or laws of the United States, or treaties made, or which shall be made, under their authority, of which the district courts of the United States are given original jurisdiction by Part I of this title, in any State court, may be removed by the defendant or defendants therein to the district court of the United States for the proper district. Any other suit of a civil nature, at law or in equity, of which the district courts of the United States are given jurisdiction, by Part I of this title, in any State court, may be removed into the district court of the United States for the proper district by the defendant or defendants therein, being nonresidents of that State. And when in any suit mentioned in this section there shall be a controversy which is wholly between citizens of different States, and which can be fully determined as between them, then either one or more of the defendants actually interested in such controversy may remove said suit into the district court of the United States for the proper district. And where a suit is brought in any State court, in which there is a controversy between a citizen of the State in which the suit is brought and 'a citizen of another State, any defendant, being such citizen of another State, may remove such suit into the district court of the United States for the proper district, at any time before the trial thereof, when it shall be made to appear to said district court that from prejudice or local influence he will not be able to obtain justice in such State court, or in any other State court to which the said defendant may, under the laws of the State, have the right, on account of such prejudice or local influence, to remove said cause. . . "

14. Dillon, Removal of Causes (3d ed. I88I) prefatory note; Note (I876) 3 So. L. REv. (N. S.) 322; Correspondence (I875) 2 CENT. L. J. 274; Editorial (1875) 2 id. 277; Legis. (I875) 7 Chicago Legal News 217. 
complete diversity of citizenship among the parties for federal jurisdiction, ought not to be followed. He intimated that removal of the entire suit on the ground of a separable controversy would be valid. ${ }^{15}$ The Judge hinted that such an attitude might be acceptable quoting from Mr. Justice Bradley's opinion in Lockart v. Horn, ${ }^{16}$ a case instituted in a federal court and decided before 1875 :

"Were this an original question I should say that the fact of a common state of citizenship existing between the complainants and a part only of the defendants, provided the other defendants were citizens of the proper state, would not oust the court of jurisdiction. It certainly would not under the Constitution. The case would still be a controversy between citizens of different states. (The Act of 1875 uses the language of the Constitution, it will be remembered.) But the strict construction put by the courts upon the Judiciary Act is decisive against the jurisdiction; and I am bound by it. . . ." ${ }^{17}$

Chancellor William F. Cooper, in a public reply to Judge Dillon's article, ${ }^{18}$ interpreted the removal of an entire suit based upon the separable controversy clause as unconstitutional. ${ }^{19}$ The Chancellor asserted that for an entire suit to come under the federal judicial power as a controversy between citizens of different states all the opposing parties must be citizens of different states. ${ }^{20}$ Shortly after Chancellor Cooper's assertion of unconstitutionality, a contributor to the Sonthern Law Review supported the constitutionality of the Act of I875, declaring that the judicial power of Article III was an adequate basis for removal of suits involving separable controversies between citizens of the same state when associated with controversies between nonresident defendants and the plaintiff. ${ }^{21}$ The argument offered, like that of Mr. Justice Bradley's, is that federal jurisdiction is not to be interpreted under the Act of 1875 as limited to controversies exclusively between citizens of different states. There should be no interpolation of the word "exclusive" into the Constitution when inspecting it for a source of authority for jurisdiction over suits containing a partial

I5. Dillon, Removal of Suits from State Courts to Federal Courts (1876) 2 So. L. REv. (N. S.) 282 .

16. I Woods 628,634 (C. C. I871). Here a suit was instituted in-not removed to-the federal court. Complainants were residents of Texas, and two of the defendants were also residents of Texas. The court refused jurisdiction. The cause was between a plaintiff and defendants, a few of them residing in the same state. Note that the past construction referred to here is related to the Judiciary Act of $I 780$, and that portion which defined the original jurisdiction of the Circuit Courts. Cf. Removal Cases, Ioo U. S. 457, 479-482 (I879) (concurring opinion) for a more complete consideration of the departure from the rulings upon the Judiciary Act of 1789 , and sub silentio distinguishing Strawbridge v. Curtiss, 3 Cranch 267 (U. S. IS06).

I7. Italics and parenthetical expression were used by Judge Dillon. Dillon, Removal of Suits from State Courts to Federal Courts (I876) 2 So. L. Rev. (N. s.) 282, 299. See also Dilion, Remioval of CaUSes (5th ed. I889) I7, 35, II5.

I8. Cooper, Removal of Causes from State to Federal Courts (I877) 3 So. L. REv. (N. S.) I.

I9. This champion of the integrity of the scope of state court jurisdiction was William F. Cooper, Chancellor for the Seventh Chancery District of Tennessee, later one of the judges of the Supreme Court of Tennessee.

20. Cooper, Removal of Causes from State to Federal Courts (1877) 3 So. L. Rev. (N. S.) r3 presents the question: Why remove the entire suit if the requirement for removal is a controversy wholly between citizens of different states that is capable of complete determination as between them?

2I. R. McP. Smith, Removal of Causes from State to Federal Courts (1877) 3 So. L. REv. (N. S.) 227. 
community of citizenship between the parties. In addition, the article attacked the use of the theory of ancillary jurisdiction, employed in order to assume control over the residual controversy between the parties of the same state, as indefensible should the judicial power be considered to extend only to controversies exclusively between citizens of different states. Ancillary jurisdiction was criticized as being "in essence a non-federal fringe upon a garment of federal jurisdiction." 22

Nevertheless, a short time after the passage of the Act of 1875 , the separable controversy clause was regarded as constitutional by the. Circuit Court of the Northern District of Illinois upon the basis. of the theory of ancillary jurisdiction. ${ }^{23}$ It was not until $\mathrm{I880}$, in Barney $v$. Latham, ${ }^{24}$ that the Supreme Court passed upon the separable controversy clause, after having reserved their opinion upon that portion of the Act of 1875 in the consideration of the Removal Cases. ${ }^{25}$

From the passage of the Act of 1875 to the present day, the Barney case ${ }^{26}$ colors the judicial approval of the practice of removal of an entire suit. This case enables federal courts to assume control over controversies involving non-federal questions between parties of the same state. It is of interest to note that in the Barney case there is no analysis of the constitutionality of the assumption of complete control over all the controversies involved. The consideration of the statute by the Court was as follows:

"But while the Act of I866, in express terms, authorized the removal only of the separable controversy between plaintiff and defendant or defendants seeking removal,-leaving the remainder of the suit, at election of plaintiff, in the state court, - the Act of I875 provides, in that class of cases, for the removal of the entire suit.

"That such was the intention of Congress is a proposition which seems too obvious to require enforcement by argument. . . . Rather than split up such a suit between courts of different jurisdictions, Congress determined that the removal of the separable controversy to which the judicial power of the United States was, by the Constitution, expressly extended, should operate to transfer the whole suit to the federal court.

"If the clause of the Act of I875, under consideration, is not to be thus construed, it is difficult to perceive what purpose there was in dropping those portions of the Act of $1866^{27}$ which, ex industria,

\section{Id. at 245 .}

0

23. Osgood v. Chicago, Danville \& Vincennes R. R., IS Fed. Cas. No. 10,604, at 879, 880 (N. D. I11. 1875). Plaintiff, a citizen of Massachusetts, instituted suit in a state court. Defendants were a railroad that was a citizen of Illinois, trustees of the railroad mortgage (citizens of states other than Illinois or Massachusetts), and creditors of the railroad who were citizens of Massachusetts. It was held that the entire suit was removable. Justice Drummon announced: "It is insisted . . . the federal court would take jurisdiction of a controversy between citizens of the same state, which would be unconstitutional. . . . If we were to admit the premises, we hardly think the conclusion would follow. ... Having control and jurisdiction of the principal, the incidents go with it. . ."

24. 103 U. S. 205 (1880).

25. 100 U. S. 457 (I879).

26. 103 U. S. 205 ( 1880 ). Heirs of $X$ who were citizens of Minnesota and Indiana sued business associates of $\mathrm{X}$ who were citizens of New York, Wisconsin, Massachusetts, and Minnesota. On appeal to the United States Supreme Court judgment of the circuit court was reversed with directive to overrule motion to remand, to reinstate cause on docket, and proceed with the case.

27. See statute quoted in note 7 sipra. 
limited the removal, in the class of cases therein provided for, to that controversy in the suit, which is distinctly between citizens of different states, and of which there could be a final determination without the presence of the other defendants as parties in the cause.

"It remains orily to inquire how far this construction of the Act of I875 controls the case now before us. . . ." 28

The above quotation is the closest approach to a consideration of constitutionality by the Supreme Court of the problem of federal jurisdiction over controversies on non-federal questions involving citizens of the same state. This is considered to be the leading case establishing such jurisdiction. Many standard reference publications cite the rule of this case without noting the limits of the opinion. ${ }^{29}$ From such reasoning there is only

28. 103 U. S. 205, 212, 213 (1880).

29. I Desty, Manual of Practice in the Courts of the United States (i899) \$ 98; Dillon, Removal of Causes (5th ed. I889) \$4I; 3 Foster, Treatise on FedERAL PRACTICE (6th ed. I92I) \$ 54I ; Lewis, Removal of CaUSES (Ig23) § I47; MONTgomery, Manual of Federal Jurisdiction and Procedure (3d ed. I927) \$290; 3 Moore \& Friednan, Moore's Federal Practice (I938) \$ Iol.06; Simkins, Fideral Practice (3d ed. 1938) § 1084; Speer, Rearoval of Causes (I888) § 28; Williams, JuRrsdiction \& Practice of the Federal Courts (19I7) II3, I30, I35.

The confusion created by the lack of a fundamentally reasoned decision in Barney v. Lathan, under the Act of 1875, and an application of the rule in that case to the equivocal Act of IgII caused one authority to announce two conflicting rules upon the subject within the space of two consecutive pages in his text. DOBIE, HANDBOoK of FEDERAL JURISDICTION (I928) 37I: "Instead of the clearer wording of the first and second sentences, 'of which the District Courts of the United States are given [original] jurisdiction by this title,' the third sentence adopts the terminology 'when in any suit mentioned in this section.' But the meaning seems to be the same, and in removals on the ground of a separable controversy it seems that the suit as filed in the state court must be one within the District Court's original jurisdiction. Both the literal interpretation of the words and the purpose and philosophy of the statute seem to justify this principle." Cf. id. at 372 : "Though the ground of removal is the separable controversy within the suit, it is well settled that the effect of the removal is to take to the federal court, not merely the controversy, but the entire suit. . . ." Query, if the scope of removal is limited to that of original jurisdiction, how can the court receive a separable determinable controversy of a non-federal question between citizens of the same state over which it has no original jurisdiction?

Id. at 345 semble: "The removal jurisdiction of the District Court is very rarely broader, frequently narrower, than its original jurisdiction. The limitations on the original jurisdiction apply to the removal jurisdiction, and there are, in addition, many restrictions on the removal of cases from a state court to the District Court which are inapplicable to cases originally instituted in the District Court."

4 Hughes, Federal Practice, Jurisdiction and Procedure (Pocket Part I945) \$2362: "The removal of a separable cause of action brings the entire case into the Federal court, although a part of it may not be removable. ${ }^{1 \mathrm{n}}$ Ia. '. . Under Const. art $3, \S 2$, Congress was authorized to provide that, when a portion of a cause is removable as a separable controversy, the entire cause is removed although not all the parties to the other controversies could come into the federal court. Sperry v. Wabash R. Co., D. C. I11. I944, 52 F. Supp. 337."

For a more critical consideration of the jurisdiction problem see MooN, ReMoval of CAuses (Ig09) 395: " $\$$ I38. Must a suit be within the original jurisdiction of a United States Circuit Court to be removable thereto from a State court under clause 3 of $\S 2$ of the act of 1875 as amended by the act of $1887-88$, known as the separable controversy clause? The meaning of clause 3 of section 2 of the present judiciary act, which is held to authorize the removal of a cause from a State court to a United States Circuit Coutrt upon the ground that it contains a separable controversy, is not clearly expressed. Its meaning is yet, in some respects, after years of litigation and many decisions construing such clause, obscure and uncertain." Also (I925) 30 ILL. L. REv. 396 . 
an inference of constitutionality. ${ }^{30}$ By nonreference to the fundamental problem of the validity of the statute, the Court announced a possible interpretation of the congressional expression concerning the breadth of federal jurisdiction under the Constitution. It is noteworthy that in this oft-cited case the entire emphasis is on the intent of Congress, ${ }^{31}$ not upon the constitutionality of their efforts; and also that the case was decided by a divided court, Chief Justice Waite, Justice Miller, and Justice Field dissenting.

A contemporary, lower federal court called attention to the conspicuous absence of fundamental reasoning in the Barney case:

"It is noticeable that the Supreme Court puts its decision in Barney v. Latham entirely upon the construction of the second clause of the second section of the Act of March 3, I875, without any reference to the constitutional difficulty. There may be no doubt about the construction of the clause, and yet the constitutional difficulty may remain. . . " 32

Later, two federal courts questioned the point of constitutionality of the removal of a controversy involving a non-federal question between residents of the same state. In one case the court said:

"The Question remains: Is this scheme constitutional in removals for separable controversy, if the suit contains other controversies to which the federal judicial power does not directly extend? Does not the Constitution exclude from the removal at least the separable controversies over which a federal court is by it given no jurisdiction? The question is of great interest and importance, affecting a mass of litigation, present and future, and possibly reaching back to judgments in the past. Though present in the law since 1875 , it seems not to have had direct consideration and authoritative consideration." 33

In another case it was said:

"The Supreme Court has never discussed the constitutionality of the provision for removal of the entire suit, containing a controversy wholly between citizens of the same state, and the lower federal courts have touched on it in but few cases. . . ." 34

The same Court that decided Barney $v$, Latham must have realized that its opinion in that case might be the starting point of a widespread practice to remove a large number of cases involving partial diversity of citizenship into the federal courts. For at the earliest opportunity, presented by Blake v. McKim, ${ }^{35}$ emphasis was placed upon the need of de-

30. Note (I928) 4I HARV. L. REv. I048, I049 n. I3: "The constitutionality of allowing removal of the whole suit because of a separable controversy, though never litigated, has so long been tacitly accepted that it is no longer open to question. . . ." Under what principle of law does tacit acceptance of a constitutional question over a long period of time equal an answer to the question?

3I. See second paragraph of the quotation from Barney $v$. Latham in text at p. 243 supra.

32. Iowa Homestead Co. v. Des Moines Navigation \& R. R., 8 Fed. 97, I05 (C. C. S. D. Iowa IS8I).

33. Hoffman v. Lynch, 23 F. (2d) 5I8, 52I (N. D. Ga. I928).

34. Texas Employers Ins. Ass'n v. Felt, 150 F. (2d) 227,233 (C. C. A. 5th, 1945).

35. I03 U. S. 336 (I880) (same term as Barney v. Lathan). A citizen of Massachusetts sued two executors of $\mathrm{X}$. One executor lived in Massachusetts, the other in New York. Held: Not removable. Controversy did not present a separable controversy; nor was it wholly between citizens of different states. 
fining the limits of such removability. It was stated that the Act of 1875 should not be extended beyond cases including a wholly separable controversy between citizens of different states. The decision suggested concern regarding an increased overcrowding of the dockets, and a distaste for too great a departure from the long established demarcation between the jurisdiction of the state and federal courts. ${ }^{36}$ The next five Supreme Court cases $^{37}$ that cite Barney $v$. Latham for the rule permitting the removal of the complete suit distinguish the cases upon factual bases. All deny jurisdiction. An additional observation supporting the assertion of a judicial attitude favoring an unannounced policy of limitation is based upon the fact that three of the opinions ${ }^{38}$ deciding against removal were written by Chief Justice Waite, one of the dissenters in Barney $v$. Latham. ${ }^{39}$ The other two opinions written by Mr. Justice Harlan, ${ }^{40}$ author of the majority opinion in the Barney case, also imposed a restrictive influence upon the factual application of the rule of that case. ${ }^{41}$

A recent high-water mark in the application of the rule of the Barney case was set by Texas Employers Insurance Association $v$. Felt, ${ }^{42}$ an action in the alternative for damages under the workmen's compensation law of Texas for the death of a husband: Suit was brought in a Texas court against three insurance companies, incorporated in California, Connecticut, and Texas. One of the nonresident defendants removed the suit to a federal court upon the basis of a separable controversy. The federal court peremptorily instructed a verdict for the two nonresident defendants, and a judgment was issued against the resident defendant. ${ }^{43}$ Upon appeal the judgment was affirmed.

Here is a clear example of the extreme position in which a federal court can be placed under the rule of Barney $v$. Latham.44 The federal judicial system, to the exclusion of the state courts, completely decided a controversy between citizens of the same state upon a non-federal question. This was accomplished by asserting a procedural right of removal over a separable controversy, which was, by requirement for removal, capable of full determination between the nonresident defendant and the plaintiff. The court again, on appeal, directs attention to the lack of a Supreme Court decision analyzing the constitutionality of such action. ${ }^{45}$ The opinion ventures to render the decision less startling by announcing that, in spite

36. There was no legislation changing the complete diversity of citizenship requirement for the right of removal from the time of the Judiciary Act of 1789 to the Act of March 3, 1875 .

37. Blake y. McKim, 103 U. S. 336 (I880) ; Hyde v. Ruble, ro4 U. S. 409 (I88I); Fraser v. Jennison, I06 U. S. I9I (I882); Thayer v. Life Ass'n of America, II2 U. S. 7I7 (I885); Brooks v. Clark, II9 U. S. 512 (I886).

38. Hyde v. Ruble, I04 U. S. 409 (I88I) ; Fraser v. Jennison, ro6 U. S. I9I (1882); Brooks v. Clark, II9 U. S. 512 (I886).

39. I03 U. S. 205 (I880). (Dissenting members: Chief Justice Waite, Justices Miller and Field.)

40. Blake v. McKim, I03 U. S. 336 (I880) ; Thayer v. Life Ass'n of America, II2 U. S. 717 (I885).

4I. 3 Moore \& Friedman, Moore's Federad Practice (I938) § xol.06. Where it is suggested that "it would be advisable to withdraw the removal privilege as to separable controversies and thus lessen the burden of litigation in the federal courts and avoid what is sometimes a difficult problem to determine, whether a controversy is separable or indivisible." Note (I936) 36 CoL. L. REv. 794.

42. 150 F. (2d) 227 (C. C. A. 5th, 1945).

43. District Court, Southern District of Texas. Opinion not reported.

44. r03 U. S. 205 (I880).

45. Judicial comment quoted in text at p. 245 supra. 
of the shortcoming of the opinion in the leading case, such action could be sustained upon a theory of ancillary jurisdiction. ${ }^{46}$

When using the theory of ancillary jurisdiction it is assumed that, once judicial control prevails over a single separable controversy between the nonresident defendant and the plaintiff, all other controversies in the suit are immediately subject to federal control. Regarding the basis for this theory of ancillary jurisdiction there are two views: one view is that control over the principal part implies control over the lesser parts; ${ }^{47}$ the other view holds that if the federal court exercises jurisdiction over a portion of a dispute it must control all portions to bring about justice in the case. ${ }^{48}$ To uphold jurisdiction under the first view, the controversy should not only be a separable controversy capable of full determination, but it also should be the principal controversy. This factor is not required for removal under the statute governing the right of removal. ${ }^{49}$ The operation of a procedural requirement of this laind would produce still greater complexity in the already confused field of removal litigation. To use the second view advanced to support ancillary jurisdiction all the controversies must go into the federal court to work justice. This is open to question. Are the state courts not capable of doing justice in the controversy between parties of the same state? Does justice arise out of the imposition of the added burden of transfer upon the similar state parties, when, by statute, the petitioner for removal is required to show that his controversy is separable and completely capable of determination when standing alone? ${ }^{50} \mathrm{~A}$ further attempt to justify ancillary jurisdiction may be made upon the argument of efficiency. ${ }^{51}$ One is forced, however, to inquire whether or not it is efficient to tax the federal courts with controversies that can be decided in the state courts merely because one nonresident party selects the federal forum to decide the controversy in which he is interested. When using the ancillary jurisdiction theory one court has acknowledged that constitutionally the lower federal courts have no independent jurisdiction over non-federal controversies between citizens of the same state.52 What, then, is the source of authority for removal jurisdiction over such controversies? ${ }^{53}$

The review of the development of the law of the removal of separable controversies illustrates the confusion and incoherence that can be caused

46. 150 F. (2d) 227,234 (C. C. A. 5th, 1945).

47. Fulton Nat'l Bank of Atlanta v. Hozier, 267 U. S. 276, 280 (Ig24). See also note 23 supra.

48. Williams, Jurisdiction and Practice of Federal Courts (rgi7) § 4.

49. Dillon, Removal of Causes (5th ed. I889) 5I: "And when this state of facts exists [a controversy capable of complete separation and determination between citizens of different states], it is immaterial whether the separable controversy be considered the main or principal one in the suit or not, or what other controversies or parties are involved in it."

50. Moon, Removal of Causes (I909) § I47 n. 7.

51. Williadis, Jurisdiction and Practice of Federal Courts (igi7) §4.

52. I50 F. (2d) 227,234 (C. C. A. 5th, I945). Query, how can this ancillary theory permit a federal court to have jurisdiction over a matter which it does not have under original jurisdiction? Such an approach would permit indirectly that which could not be done directly.

53. The process of removal was designed to eliminate the existence of injustice due to possible state prejudices and not to allow the plaintiff to destroy the nonresident defendant's privilege of the federal forum by instituting a suit in a state court. It was not invented to encroach upon the judicial activity of the state courts. A statutory change in the scope of federal court jurisdiction should be construed with a high regard for the limits of the grant of federal judicial power within the Constitution. See Dobie, HaNdBook of Federal Jurisdiction (1928) 347. Quoted note 5 supra. 
by the poor draftsmanship of a statute. ${ }^{54}$ This is especially so in the right of removal, where the entire law of the subject is founded upon a statutory origin. ${ }^{55}$ The enactment is not clear in stating whether the right of removal, under the separable controversy clause, is to be limited by the long established rule of original jurisdiction, ${ }^{56}$ or increased by the creation of a new and different type of federal jurisdiction. ${ }^{57}$ The case of Barney v. Latham ${ }^{58}$ presents little assistance for the interpretation of the present Act. The Court in the Barney case, dealing with the Act of 1875 , did not discuss the constitutionality of federal jurisdiction over non-federal controversies between citizens of the same state, but considered only the intent of Congress to remove the entire suit. ${ }^{59}$ The fact that the extent of federal judicial power might be changed escaped attention. It is a source of amazement that so fundamental an issue as the broadening of the jurisdiction of the lower federal courts has not been reviewed in relation to the constitutional grant of federal judicial authority.

The law under the removal statute is still in a state of conflict. Barney v. Latham ${ }^{60}$ has not been overruled. The decision is still used to enable a lower federal court to try a case wherein the opposing parties share a partial community of citizenship. ${ }^{61}$ In a later consideration of a clause in the Act of 1887 governing removal because of local prejudice, ${ }^{62}$ the Court, however, specifically announced that that portion of the Act does not include cases "wherein the controversy was partly between citizens of the same State." "3 It stated: "To hold otherwise brings the language of the clause into conflict with the rule that a suit to be removable must be within the original jurisdiction of the Circuit Court, departs from the

54. Dillon, Removal of Causes (5th ed. i889) 5 i Speer, Removal of Causes (I888) § 35; Andrews, Federal Removal Confusion (I936) 9 Miss. L. J. I88, 192: "The Act of 1887 , corrected in 1888 , is the present removal statute, and for that reason merits a special examination. It would seem that from its very inception there was confusion concerning its provisions. Although the act, when printed in the statute books, conformed to the enrollment, the enrolled act, when compared with the original papers on file in the secretary's office, contained twenty-five mistakes in spelling, in punctuation, in changing and omitting words, and in the structure of the bill. It is difficult to find the exact intentions of the framers of the bill due to the fact that there is only a slight account in the Congressional Record of the proceedings of the Senate and the House in regard to the measure.

55. Chicago \& Northwestern R. R. v. Whitton's Adm'r, 80 U. S. 270, 287 (1871);

Wenzler v. Robin Line S. S. Co., 277 Fed. 8I2, 8I9 (W. D. Wash. I92I).

56. Strawbridge v. Curtiss, 3 Cranch 267 (U. S. 1806).

57. Dobie, Handeoor of Federal Jurisdiction (I928) 372; 4 Hughes, Federal Practice, Jurisdiction ANd Procendure (Pocket Part I945) \$ 2362.

58. I03 U. S. 205 (I880).

59. See quotation of a portion of the decision in the text at pp. 243-4 supra.

60. I03 U. S. 205 (1880).

6r. Texas Employers Ins. Ass'n v. Felt, I50 F. (2d) 227 (C. C. A. 5th, 1945), discussed in text, p. 246 supra.

62. Act of March 3, I887, 24 STAT. 552 (I886); and the correction of that Act by the Act of August 13, 1888, 25 STAT. 433, 434 (1889), 28 U. S. C. A. $\$ 7$ I (1927): "And where a suit is now pending, or may be hereafter brought, in any State court, in which there is a controversy between a citizen of the State, in which the suit is brought and a citizen of another State, any defendant, being such citizen of another State may remove such suit into the circuit court of the United States for the proper district, at any time before the trial thereof, when it shall be made to appear to said circuit court that from prejudice or local influence he will not be able to obtain justice in such State court, or in any other State court to which the said defendant may, under the laws of the State, have the right, on account of such prejudice or local influence, to remove said cause. . . ." Note, p. 8. Mark the similarity to the Act of I9II, which is quoted in note 13 supra.

63. Cochran v. Montgomery County, I99 U. S. 260, 272 (I905). 
settled former construction, and ignores the main purpose of the act of 1887, which was to restrict the jurisdiction of the Circuit Court. . . ." 64

An attempt to explain away the conflict and produce an apparently uniform concept of the scope of the lower federal court jurisdiction under the present removal statute is impossible. The statute, in spite of its seventy years of existence, continues to possess an inherent ambiguity, a defect that might well have been caused by a lack of thorough study of the complexities of the subject at the time of its origin. ${ }^{65}$ A statute of such jurisdictional importance should command the attention of the legislature for the purpose of revision and restatement, a task that should not be placed indirectly upon the courts.

$$
\text { J. L. E. }
$$

64. Ibid. In addition: "But the fourth clause, treating of removals because of prejudice or local influence, does not furnish a separate and independent ground of Federal jurisdiction, and, as Mr. Justice Bradley said in In re Pennsylvania Company, I37 U. S. 45I, 456, 'describes only a special case comprised in the preceding clauses.' ..."Id. at 270 .

65. Frankfurter \& Landis, Bustness of the Supreme Court (1927) I3: "Legislation concerning judicial organization throughout our history has been a very empiric response to very definite needs." See also notes II and 54 supra. 